\title{
Artelogie
}

Recherche sur les arts, le patrimoine et la littérature de I'Amérique latine

$11 \mid 2017$

Délocalités, translocalités et activisme dans l'art électronique et biomédiale latino-américain

\section{Estética de la emergência: la formación de otra cultura de las artes. De Reinaldo Laddaga. Adriana Hidalgo editora. 1.ed. Buenos Aires, 2006.}

\section{Priscila Arantes}

\section{(2) OpenEdition Journals \\ Edición electrónica \\ URL: http://journals.openedition.org/artelogie/1612 \\ DOI: 10.4000/artelogie. 1612 \\ ISSN: 2115-6395 \\ Editor \\ Association ESCAL \\ Referencia electrónica \\ Priscila Arantes, «Estética de la emergência: la formación de otra cultura de las artes. De Reinaldo Laddaga. Adriana Hidalgo editora. 1.ed. Buenos Aires, 2006. ", Artelogie [En ligne], 11 | 2017, mis en ligne le 28 décembre 2017, consulté le 23 septembre 2020. URL : http://journals.openedition.org/ artelogie/1612 ; DOI : https://doi.org/10.4000/artelogie.1612}

Este documento fue generado automáticamente el 23 septembre 2020.

Association ESCAL 


\title{
Estética de la emergência: la formación de otra cultura de las artes. De Reinaldo Laddaga. Adriana Hidalgo editora. 1.ed. Buenos Aires, 2006.
}

\author{
Priscila Arantes
}

1 Estética de la emergência: la formación de otra cultura de las artes de Reinaldo Laddaga traça, de forma precisa e multidisciplinar, discussões no âmbito da filosofia, teoria das mídias, sociologia, literatura e artes visuais no intuito de sinalizar para o advento de um novo momento da cultura e das artes vinculado a processos mais amplos de mutações das formas de ativismo político, produção econômica e investigação científica.

2 Para o autor vivenciamos um momento de transição na cultura e nas artes comparável ao que aconteceu na passagem do século XVIII para o XIX, ou seja, do período correspondente às configurações dos paradigmas e postulados da modernidade estética "que se organizaba en torno a las diversas figuras de la obra como objetivo paradigmático de prácticas de artista que se materializaban en las formas del cuadro o el libro, que se ponían en circulación en espacios públicos de tipo clássico y se destinaban a un espectador o un lector retraído y silencioso, al cual la obra debía sustraer" (Ladagga, 2006 p7).

3 O estabelecimento deste modus operandi no sistema das artes da modernidade foi simultâneo à configuração das formas de organização disciplinares - tais como descritas por Michel Foucault - que assumiram a fórmula geral de dominação exercida em diversos espaços durante séculos passados; escolas, hospitais, presídios e instituições culturais. 
4 As instituições configuravam-se, neste sentido, como uma combinação de controle social e moral visando docilizar e colonizar os comportamentos e os corpos, adequando-os e formatando-os ao modo de produção social disciplinar.

5 Estética da emergência aponta, exatamente, para um novo e diferente mundo da cultura, fruto da crise do modelo disciplinar. Isto não quer dizer que as instituições culturais "disciplinares" deixam de existir, mas é perceptível que estes espaços entram em colapso para dar vazão a novas formas de organização e produção cultural mais "inclusivos":

Esta configuración se desplegaba al mismo tiempo (y en los mismos lugares) que lo hacían las formas de organización y asociación de esa modernidad que Foucault llamaba "disciplinaria": modernidad del capitalismo industrial y el Estado nacional. Por eso no es casual que ambas cosas entraran en crisis a la vez (...) (Ladagga, 2006 p7)

6 A publicação coloca em debate, neste sentido, projetos criativos que se articulam em redes de colaboração entre artistas e não-artistas e que, menos do que produzir obras de arte no sentido modernista do termo, se agrupam para participar da formação de ecologias culturais.

7 São projetos que implicam, muitas vezes, na implementação de formas de colaboração que permitem colocar indivíduos de diferentes proveniências e lugares operando em relações de alteridade em um pensamento de troca de saberes e em processos de aprendizagem coletiva voltados, muitas vezes, para situações concretas da realidade cotidiana.

8 O autor reúne, assim, em nove ensaios, uma série de projetos desenvolvidos após os anos 90 no campo interdisciplinar das artes cênicas, artes visuais, literatura, audiovisual e que, para além de terem sido organizados dentro dos formatos tradicionais de exibições de arte, se manifestam através de grupos colaborativos conectados, muitas vezes, com um lugar de encontro, atuando nas formas de vida e no bem comum. What's the time in Vyborg (Vyborg/ Rússia); Park Fiction (Hamburgo/ Alemanha), Wu Ming (Itália); The Venus Project (Flórida/EUA; são alguns dos projetos analisados em Estética da Emergência.

9 O espectador destes projetos, longe de ser "retraído e silencioso" torna-se colaborador ativo integrado aos processos de criação, guiado por trocas pós-disciplinares e transdisciplinares - comunidades experimentais de resistência - que resultam em “objetos fronteiriços" ou em proposições de sociabilidade e práticas de convívio que repensam o próprio espaço comum.

10 Analisando produções que atuam em um campo expandido de linguagens, Laddaga traz a tona projetos que se orientam dentro do que ele nomeia de um regime prático das artes, e não mais estético (no sentido modernista do termo) - dado na localidade e na aproximação legítima da arte com a vida e com o comum:

11 Cuando a comienzos de los ãnos 90, tras interregno del pos-modernismo "realmente existente", se volviera crecientemente frecuente que individuos formados em la trádicion moderna de las artes se abocaran a prácticas que suponían menos la realizacíon de objetos concluidos que la exploración de modos experimentales de coexistencia de personas y de espacios, de imágenes y tiempos, sus acciones, sin embargo, responderían a una coyuntura particular (Laddaga, 2006 p 45). 
12 Sem fazer distinções entre o vivente e o não-vivente, e reconhecendo a importância da produção de objetos materiais para o entendimento do mundo social, e dos elementos não-humanos como agentes constituintes do processo organizativo, Laddaga estabelece paralelos entre o que ele nomeia de estética da emergência - ou seja, do advento destas formações não institucionais que se dão de forma colaborativa e em rede - com o conceito de emergência advindo das ciências complexas e com os projetos de programação de código aberto como o Linux:

la forma de organización propia de la comunidad del fuente abierta (que está en la práctica organizada en torno a proyectos, procedimientos de comunicación, instrumentos de comunicación y módulos de software que evolucionan constantemente ) no es simplemente azarosa ni se ha desarrollado de manera espontánea, sino que su desarrollo se basa en un sistema complejo de relaciones sociales, valores, expectativas y procedimientos (...) Se entiende por qué la programación en fuente abierta es un motivo de reflexión constante entre los participantes de los proyetos que hemos estado describiendo: es que allí se ensaya uma gestión de lo común que no depende de modelos de colectivización disciplinarios. (Laddaga 2006 p 277).

Laddaga, com este livro, constrói uma tessitura clara e crítica, reflexiva e contundente para mostrar as modificações da cultura em tempos pós-fordistas e pós-disciplinares. Abre, assim, nossos olhos e demais sentidos para o cenário singular da atualidade.

Onze anos após a edição de sua primeira publicação em 2006 na Argentina, pela editora Adriana Hidalgo, é possível dizer que muitas das questões colocadas em Estética da emergência parecem reverberar no mundo atual, especialmente nos países da América Latina, como o Brasil em que é visível a crise e o impasse de muitas instituições culturais.

15 O que se percebe, no caso específico do Brasil, é um enfraquecimento crescente do papel do Estado na defesa da democratização cultural entendida, neste contexto, não somente como o acesso à cultura, mas também como o atendimento à diversidade cultural. O que se vê, muitas vezes, é um desmantelamento da área da cultura, especialmente em tempos de crise econômica e política, considerada, dentro do pensamento neoliberal, como uma área de menor importância frente a outras do Estado.

16 O questionamento do papel institucional vem acompanhado, especialmente no que diz respeito à esfera pública, por uma percepção de um descompasso profundo entre as práticas institucionais - que muitas vezes se direcionam exclusivamente ao desenvolvimento de propostas espetaculares e midiáticas - e ações que possam criar um diálogo e uma participação efetiva e inclusiva do corpo social.

Percebe-se muitas vezes, dentro deste contexto, o advento de grupos autônomos e de iniciativas independentes mais experimentais entre artistas e não-artistas no sentido de criar práticas mais oxigenadas frente à realidade do nosso tempo.

18 A cultura, nessa paisagem, pode ser vista tanto como uma arca fúnebre e fria calculada e calculável - em que silenciados somos fadados a seguir os programas da caixa preta -como diria Vilém Flusser - ou, como em um circuito paralelo, pode nos permitir construir caminhos alternativos para reassumirmos o lugar da nossa experiência e vivência na constituição do sentido que damos ao mundo. 


\section{AUTOR}

\section{PRISCILA ARANTES}

Priscila Arantes é pesquisadora e curadora em arte e estética contemporânea. É pós doutora pela Penn State University (USA) e doutora em Comunicação e Semiótica pela PUC/São Paulo. É professora titular de Arte e Tecnologia do Doutorado em Design da Universidade Anhembi Morumbi e Vice-coordenadora do Curso de Arte: história, crítica e curadoria da PUC/SP.É diretora artística e curadora do Paço das Artes, instituição da Secretaria de Estado da Cultura desde 2007.Entre seus livros destacam-se: Arte@Midia: perspectivas da estética digital (2012, 2ed.) e Reescrituras da Arte contemporânea: história, arquivo e mídia (2015).Entre os prêmios recebidos destacam-se: Society of Latin American Studies (2016), Getty Foundation (2016) e o 48 Prêmio Jabuti (finalista) pela publicação Arte@Mídia. 